\title{
The Question of Multiculturalism in the Arts in the Postcolonial Nation-State of Trinidad and Tobago
}

\author{
JOCELYNE GUILBAULT
}

The adoption of "multiculturalism" as an official policy in many nation-states has generated endless debate, not only among state officials, but also among academics and social activists. What is being debated is the essential governability of multicultural communities living together in a given nation-state-who has the authority to create norms and social hierarchies within society or to exclude anyone and on what basis. The tensions raised by the issue of "multiculturalism" have thus to do with power itself, and the relationships within and between groups. In this sense, multiculturalism is predominantly a political question.

Stuart Hall draws an important distinction between the terms "multicultural" and “multiculturalism.” In his words,

Here multi-cultural is used adjectivally. It describes the social characteristics and problems of governance posed by any society in which different cultural communities live together and attempt to build a common life while retaining something of their 'original' identity. By contrast, 'multiculturalism' is substantive. It references the strategies and policies adopted to govern or manage the problems of diversity and multiplicity which multi-cultural societies throw up. It is usually used in the singular, signifying the distinctive philosophy or doctrine which underpins multi-cultural strategies. 'Multi-cultural,' however, is by definition plural. ${ }^{1}$

As several authors point out, one of the dangers of using multiculturalism as a basis for policy is that it views communities as static. In turn, the multicultural question is often framed in terms of the two traditional categories of "race" and ethnicity. Even though, as Hall explains, "the differences attributed to 'race' within a population are as great as those between racially defined populations, 'race' . . a political and social construct . . is the organizing discursive category around which has been constructed a system of socio-economic power, exploitation and exclusion-i.e. racism." ${ }^{2}$ And as Hall further notes, even though ethnicity is usually contrasted against "race" by being defined in terms of cultural and religious features, these features, described as fixed and transmitted from generation to generation and through intermarriage, are also viewed as creating a "chain of equivalences" going from culture to nature—and thus as being genetically related. He concludes, "It seems therefore more appropriate to speak, not of 'racism' $v s$ cultural difference', but of racism's 'two logics."”

Another version of this paper was first presented as a keynote address at the conference entitled "Multiculturalisms and the Arts," Turku, Finland, 29-30 August, 2008. I want to thank the organizers, and especially Pirkko Moisala for inviting me to write on the subject. I also want to thank the anonymous readers for their helpful suggestions which helped me sharpen my argument.

${ }^{1}$ Stuart Hall, “Conclusion: the Multi-Cultural Question,” In Un/Settled Multiculturalisms: Diasporas, Entanglements, Transruptions, ed. Barnor Hesse, 209-41 (New York: St. Martin’s Press, 2000), 209.

${ }^{2}$ Hall, 223.

${ }^{3}$ Ibid. 
Apart from the danger of essentializing communities, the concept of multiculturalism, at least for some critics, contains irreconcilable contradictions. As Lisa Lowe remarks, while ideologically it aims to promote multicultural inclusion, multiculturalism simultaneously divides communities and people into separate categories-as Black, as Asians, as Chicanos. Speaking about the issue of multiculturalism in the United States, she writes: "It is this isolation of objects that contributes to the fragmentation of social life in the capitalist USA and this isolation likewise contributes to the fragmentation of political organization against the interlocking dominations." "It could be added that the creation of these distinct categories has fuelled a belief in the incommensurability of different cultures and given way to cultural relativism-a perspective that, in Satya Mohanty's words, "demands that we suspend judgment on purely a priori grounds." This version of multiculturalism, many critics complain, is not conducive to developing multicultural inclusion. As Mohanty remarks, it offers at best a weak pluralist scenario of noninterference and peaceful coexistence based on an abstract notion that everything about the other culture is (equally) valuable. Given the lack of understanding or knowledge of the other, however, the ascription of value (and of equality among cultures) is either meaningless or patronizing."

In each case, whether its tangible effects have been to encourage racism or noninterference or, in the best scenario, multicultural inclusion, the goal of multiculturalism has remained the same: to govern or manage the problems of diversity and multiplicity in a given society. If, as I suggested above, the question of multiculturalism is ultimately a question of power, about who has the authority to conduct the conduct of others-to paraphrase Michel Foucault's famous expression-the problems multiculturalism and its proponents encounter are manifold. One of these problems is the increasingly rapid pace at which these communities change and enact hybrid formations, a situation born of greater access to mass communication and transportation. The pace and nature of such change means that cultural communities challenge not only the authorities and experts who attempt to define them, but also the categorizations that have often contributed to their isolation and marginalization.

Another problem faced by multiculturalism, as a policy to manage diversity, is that the activities associated with particular cultural communities increasingly escape the control of the state government either by taking place and being coordinated locally, or supranationally, through "corporations and the international nongovernmental sector (UNESCO, foundations, and nongovernmental organizations)," among others. ${ }^{7}$ The question of norms is thus escalating, both because hybrid formations draw their sense of values from different cultures, and because distinct communities conceive and perform their activities in terms of an increasingly complicated web of relationships and values.

Yet another problem has to do with the power of consumers. In a capitalist neoliberal era, what sells acquires political weight. The management of diversity is thus greatly influenced by what acquires value for the majority of the population. For example, the $\$ 400$ million earned by the city of Toronto during Caribana $^{8}$ over the past few years—one, if not the most important Trinidadian-inspired Carnivals outside

\footnotetext{
${ }^{4}$ Lisa Lowe, "Imagining Los Angeles in the Production of Multiculturalism," in Mapping Multi-Culturalism, ed. Avery F. Gordon and Christopher Newfield, 413-23 (Minneapolis: University Press of Minnesota Press, 1996), 420.

${ }^{5}$ Satya Mohanty, "Epilogue. Colonial Legacies, Multicultural Futures: Relativism, Objectivity, and the Challenge of Otherness," PMLA 110, no. 1 (1995): 113.

${ }^{6}$ Ibid.

${ }^{7}$ I draw this quote from George Yúdice's inspiring book, The Expediency of Culture, when he discusses the notion of culture as a resource and its management (2003:4).

8 "Caribana" by Gillian Downes in The Toronto Times, August 3, 2008. http://thetorontotimes.com/content/view/234/63/, accessed on 11 August 2008.
} 
of the Caribbean-may have contributed to the creation of the calypso category in the annual JUNO national music awards in Canada. ${ }^{\text {? }}$

Multiculturalism as a policy recognizes that multicultural heterogeneity constitutes a productive force, one that is highly influential on the socio-political dynamics of a country. As David Theo Goldberg explains,

Multicultural heterogeneity politicizes explicitly what is otherwise political only silently and in the absence of acknowledgment (that is, what gets denied as political in the name of universal value). It renders explicit the contestation over values and entitlements making overtly political what in any case is implicitly so and, thus, reduces the possibility of manipulation and control as well as maintenance of the status quo. Finally, multicultural heterogeneity multiplies in number and quality the available nature and range of knowledge and practical wisdom. And given that heterogeneity applies equally within and between groups, it likewise sets a limit on intragroup tyranny as it delimits inter-group oppression. ${ }^{10}$

The question is, why has culture, and more precisely, the arts, been a primary target for multiculturalism? Several authors have offered different reasons. Speaking about the United States, Avery F. Gordon and Christopher Newfield indicate that some believe that "any discussion of cultural diversity would render racism [or class antagonism] insignificant" and that "equal respect would replace common culture as a nation's social cement." 11 They conclude that the focus on culture-and thus, by extension, the arts-is based on the traditional belief in its ability to transcend social forces and to give multicultural communities a position of independence and strength. In the same vein, as Gordon and Newfield report, multiculturalist educators like Cary Nelson believe that by familiarizing people with different traditions, schooling can provide "'a new conversational terrain,' one that can 'fundamentally reorder the ruling definitions of culture' and the distribution of power and resources." 12 In other words, a better understanding of culture can help bring political change.

The problem for many is that multiculturalism seems typically to involve only the (re)presentation of the diversity of cultures on national platforms and an acknowledgement of the coexistence of diverse groups. As Lowe remarks, it fails "to address the systemic inequalities built into cultural institutions, economies, and geographies." ${ }^{\prime 3}$ Echoing many critics of multiculturalism, she stresses how such policy is highly misleading: "To the degree that multiculturalism claims to register the increasing diversity of populations, it precisely obscures the ways in which that aesthetic representation is not an analogue for the material positions, means, or resources of those populations . . . The production of multiculturalism instead diffuses the demands of material differentiation through the homogenization, aestheticization, and incorporation of signifiers of ethnic differences." ${ }^{14}$

\footnotetext{
${ }^{9}$ The JUNO awards refer to the Canadian music industry awards. It was named after the then head of the CRTC, Pierre Juneau, in 1965. After being instituted in the early 1990s, the category of calypso, however, was dropped a few years later for reasons that still need to be investigated. I thank Jai Ojah-Maharaj for sharing this information with me.

${ }^{10}$ David Theo Goldberg, "Introduction: Multicultural Conditions," in Multiculturalism, a Critical Reader, ed. David T.

Goldberg, 1-44 (Oxford: Basil Blackwell, 1994), 32.

${ }^{11}$ Avery F. Gordon and Christopher Newfield, eds., "Introduction,” Mapping Multi-Culturalism, (Minneapolis: University

Press of Minnesota Press, 1996), 3-4.

${ }^{12}$ Ibid., 6.

${ }^{13}$ Lowe, 421.

${ }^{14}$ Ibid., 414-15.
} 
By contrast, other authors understand multiculturalism's focus on culture and the arts as a resource "for both sociopolitical and economic amelioration, that is, for increasing participation in this era of waning political involvement, conflicts over citizenship." ${ }^{15}$ Put another way, Jeremy Rifkin (2000) views multiculturalism's focus on the arts as participating in the rise of what he calls "cultural capitalism." 16 As George Yúdice aptly remarks, the relation between culture and politics or culture and economics is not new. What marks a change in this neoliberal era is the fact that, at least in the United States, state support for culture is nearly dead and artistic activities performed under the umbrella of multiculturalism have been turned into the "property" of the new political economy. Expressions such as "heritage industry," "cultural economy," or "creative economy" that have entered the common vocabulary in many countries are telling. In this context, Yúdice suggests, "The content of culture recedes in importance as the usefulness of the claim to difference as a warrant gains legitimacy. The result is that politics trumps the content of culture." ${ }^{17}$ While it may be increasingly difficult to think about creative activities without paying attention to the political economy in which they take part, to suggest that politics trumps the content of culture, in my view, overlooks at least two crucial elements. Speaking against both the reduction of culture to instrumental politics and an economistic understanding of creative activities, Line Grenier convincingly argues, "it not only ignores the artistic investment and the positioning of its makers, but also neglects the aesthetic discrimination and value judgments of its consumers." ${ }^{18}$ In all cases, whether it is for liberal education, client-focused goals, or instrumentalist politics, I agree with Yúdice that "today it is nearly impossible to find public statements that do not recruit instrumentalized art and culture" to deal with the governability of diversity, be it in terms of social conditions or economic growth.

\section{II}

Most of the writings referenced have for the most part focused on European and North American countries. In the second part of this paper, I would like to shift this focus in two ways, firstly by changing the location where multiculturalism is discussed. In contrast to most publications on Canada, the United States, or Britain that address multiculturalism in relation to the so-called problem of immigration, I want to concentrate on a postcolonial Caribbean nation-state, and more specifically on the twin-island state of Trinidad and Tobago (Trinidad hereafter) where the question of diversity is not posed this way. Unlike say India, or Nigeria, Caribbean nation-states largely have been constituted of migrants through forced or free migration after nearly all aboriginal populations were decimated by diseases contracted from European settlers. I focus on Trinidad in particular because its population by any standard is judged to be one of the most multicultural in the region. Today Trinidad has approximately 1.3 million inhabitants. However, to give only a summary of the demographics of the country would reduce the complexities of Trinidadian society to such a degree it would be misleading. For this reason, I have included the last demographic report (2008) in its entirety:

\footnotetext{
${ }^{15}$ Iris Marion Young, Inclusion and Democracy (New York: Oxford University Press, 2000), 81-120.

${ }^{16}$ Quoted in George Yúdice, The Expediency of Culture: Uses of Culture in the Global era (Durham: Duke University, 2003), 9-10. ${ }^{17}$ Yúdice, 23. Emphasis in the original.

${ }^{18}$ Quoted in Jocelyne Guilbault, Governing Sound: The Cultural Politics of Trinidad's Carnival Musics. (Chicago: University of Chicago Press, 2007), 5.
} 
The ethnic composition of Trinidad reflects a history of conquest and immigration. Two major ethnic groups-Indo-Trinidadians and Afro-Trinidadians-account for almost $80 \%$ of the population, while people of mixed-race, Euro-Trinidadian/European, Chinese Trinidadian/Chinese and Arab-Trinidadian/Syrian-Lebanese descent make up most of the rest of the population. According to the 1990 census, Indo-Trinidadians make up $40.3 \%$ of the population, Afro-Trinidadians 39.5\%, Mixed-race people 18.4\%, Euro-Trinidadian $0.6 \%$ and Chinese, Lebanese, Syrians and others $1.2 \%$. Euro-Trinidadians, especially those descendants of the former plantocracy, are often referred to as French Creoles, even if they are descended from Spanish, British, or German settlers. The mixed-race Cocoa Payols are descendants of the original Spanish settlers and later immigrants from Venezuela. Today, the Trinidadian Portuguese population includes both whites and mixed people. The small Amerindian population is largely mixed-race. The Carib population, which is descendant of the indigenous inhabitants, is primarily organised around the Santa Rosa Carib Community. ${ }^{19}$

Bearing in mind these statistics, I would like first to highlight some of the elements that distinguish the postcolonial state of Trinidad from the former colonial powers. I will then explore the main issues that are conceived as confronting the arts of governing multicultural communities in this postcolonial society. What is the role of the arts in addressing these issues? What are the technologies used to govern the multicultural society? And to what effect?

My second shift has to do with the way power has been conceived in the majority of discussions on multiculturalism. In contrast to most publications on the subject, which address the issue of power exclusively in terms of the state, I want to highlight other forces that have also played a significant role in governing multicultural communities in Trinidadian society. ${ }^{20} \mathrm{I}$ am referring here to privately owned corporations, particular individuals, and specific historical and political events that have had significant outcomes on how the multicultural question has been addressed in the country at different moments in its history.

\section{Distinct Realities and Positioning of Diversity in Trinidad}

Unlike England or the United States, whose concerns about multiculturalism have been linked to the increasing presence of immigrants, the multicultural question in Trinidad is informed by the power struggles among discrepant diasporas. Significantly, as will be shown below, some of the most important issues raised in the governing of diversity in Trinidad have been vehemently debated nearly exclusively by the two most important diasporas in the country, African and East Indian. The debates have centered on the issues of national representation and equality in relation to participation in decision-making and the sharing of material wealth in the country.

Trinidad's society bears the legacy of its colonial past and a system of stratification based on a classrace-color hierarchy. As Percy Hintzen writes, "the organization of colonial society rendered social and

\footnotetext{
${ }^{19}$ http://en.wikipedia.org/wiki/Trinidad_and_Tobago\#Demographics, accessed on 7 July 2008. The expression "East Indian" is used locally to refer to people of Indian descent born in Trinidad and to distinguish these people from Indians born in India and from the Arawak, the Carib, and the Taino-the first inhabitants of the island.

${ }^{20}$ This insight draws on Michel Foucault's notion of governmentality which views governing power as "not rest[ing] with some unifying principle of central power (the sovereign, the state)," but rather as being informed by the simultaneous diversity of projects and technologies that are specific to different agencies and their different forms of management (Tony Bennett quoted from Guilbault (2007: 4)). For further elaboration on the subject, see Foucault (1979).
} 
economic boundaries more or less coterminous with those of race, culture, religion, language, tribe, or other manifest communal distinctions." Furthermore, he adds, "These communal segments were generally differentially incorporated into the various strata of colonial society." ${ }^{21}$ Not surprisingly then, this unequal incorporation into colonial society led communal groups to develop conflicting socio-economic interests. On the eve of Trinidad's Independence, the Afro- and Indo-Trinidadians continued to bear the divisive legacy of the colonial regime and to function as two separate groups. As I wrote elsewhere, ${ }^{22}$

Hence, in 1956 after the decisive creation of the People's National Movement (PNM)-the first party government of the country which, headed by an Afro-Creole ${ }^{23}$ Oxford-trained scholar, Dr. Eric Williams, was to lead the British colonies of Trinidad toward national independence in 1962 - the struggle over power, politically and culturally, now unfolded between a two-party system: the PNM and the opposition, the Democratic Labor Party consisting of a variety of groups with a clear East Indian preponderance, including the PDP (the People's Democratic Party) - the main opponent to the PNM in the 1956 elections. ${ }^{24}$ With a two-party system in place, the ethnic demarcation between the blocs proved an ominous sign for the future. While the new political structure celebrated a culturally hybrid Trinidad, it also consolidated racialized voting blocs, leading to "the development of opposed bourgeois nationalist Afro-Creole and [East] Indian political parties" and hence, an "us" and "them" mentality. ${ }^{25}$

The inheritance of "ethnic group competition, fostered by class inequalities and state control of certain resources, and couched in terms of racial antipathies between Indo- and Afro-Trinidadians" deeply inform the postcolonial society of Trinidad to this day. ${ }^{26}$ The historical tensions between the two groups have indeed gone unabated in spite of their numerous interactions and collaborations in many sectors of activity.

In this context, multiculturalism in Trinidad is thus not about how a "monoculture" addresses the so-called disruptive presence of migrants, but rather about how, out of diversity, unity can be created. ${ }^{27}$ The premise in this vision is that the state of Trinidad is neutral. In 1962, when Trinidad became independent, Eric Williams, the first prime minister of the new nation-state, addressed multicultural diversity in no uncertain terms. His goal was to create a single allegiance out of diversity and, as Puri puts it, "to manage difference by projecting an image of nonconflictual diversity." 28 In Williams's words,

\footnotetext{
${ }^{21}$ Percy C. Hintzen, The Costs of Regime Survival: Racial Mobilization, Elite, Domination and Control of the State in Guyana and Trinidad (Cambridge: Cambridge

University Press, 1989), 6.

${ }^{22}$ Guilbault, 27-28.

${ }^{23}$ The term "Afro-Creole" refers to a person born in Trinidad of European and African descent. The word "Creole" in Trinidad has been the subject of numerous definitions over time. For further information on the subject, see Brereton (2002), Hintzen (1999), and Khan (2004).

${ }^{24}$ Koningsbruggen (1997: 117).

${ }^{25}$ Puri (1999: 17).

${ }^{26}$ Aisha Khan, Callaloo Nation: Metaphors of Race and Religious Identity among South Asians in Trinidad (Durham: Duke University Press, 2004), 9.

${ }^{27}$ It is important to stress that the notion of diversity at the time of Trinidadian independence and until only recently wasand in many ways, continues to be-very selective. It was not conceived in terms of sexual orientations, gendered roles, or generations, but instead almost exclusively based on ethnicity and religion.

${ }^{28}$ Puri, The Caribbean Postcolonial: Social Equality, Post-Nationalism, and

Cultural Hybridity (New York: Palgrave Macmillan, 2004), 48.
} 
There can be no Mother India for those whose ancestors came from India.... There can be no Mother Africa for those of African origin, and the Trinidad society is living a lie and heading for trouble if it seeks to create the impression or to allow others to act under the delusion that Trinidad is an African society. There can be no Mother England and no dual loyalties; no person can be allowed to get the best of both worlds, and to enjoy the privileges of citizenship in Trinidad whilst expecting to retain United Kingdom citizenship. There can be no Mother China, even if one could agree as to which China is the mother; and there can be no Mother Syria or Mother Lebanon. A nation, like an individual, can have only one mother. The only Mother we recognize is Trinidad, and Mother cannot discriminate between her children. ${ }^{29}$

In this vision, governing multicultural communities means-at least conceptually-focusing on the hybrid formations produced from cultures as different as African, Indian, Chinese, Syrian, and Lebanese, among others. As Puri explains, such a nationalist discourse on hybridity, typical of most Caribbean nationbuilding projects, "elaborate[d] a syncretic New World identity, distinct from that of its 'Mother Cultures'; in doing so, [it] provide[d] a basis for national and regional identity." ${ }^{30}$ Puri adds, "If Williams is to legitimize a Trinidadian nation, he must produce it as both hybrid and homogeneous." Furthermore, influenced by the colonial powers' emphasis on the unitary Enlightenment subject, he must also turn the hybrid Trinidadian subject "into a stabilized, unitary subject with exclusive affiliations." ${ }^{1}$ However, by adopting this rationality, the newly-elected state government in Trinidad faced the paradox typical of the modern nation-state: insisting on creating unity out of diversity, while at the same time officially recognizing the need to manage diversity in ways that respect difference and promote each people's heritage. ${ }^{32}$ In such a context, the question is: how does a nation-state like Trinidad then represent itself? Who is the national subject and how is it imagined?

Part of the answer, it should be noted, is that the hybridity to which Williams refers is cultural, not racial. As Puri explains:

The tendency to play up cultural hybridity as a way of playing down racial hybridity is a recurrent move of many foundational Caribbean nationalist invocations of cultural hybridity.... Trinidadian nationalist (and regional) politics have resorted to tearing apart the fabric of "the people" along racial lines, developing opposed bourgeois-nationalist Afro-Creole and Indian political parties. For this reason, although Williams requires cultural hybridity for his national project, he cannot afford racial hybridity; the races must be kept distinguishable and apart. The rhetoric of cultural hybridity in Trinidadian national politics, then, has been linked to state "divide and rule" racial politics." 33

From this perspective, the role of the arts in addressing the multicultural question is encumbered with numerous vested interests, and becomes the subject of endless debates.

\footnotetext{
${ }^{29}$ Eric Williams, History of the People of Trinidad (Port of Spain, 1962), 281.

${ }^{30}$ Puri, The Caribbean Postcolonial, 45.

${ }^{31}$ Williams, History of the People of Trinidad, 48.

${ }^{32}$ See Aisha Khan's important book, Callaloo Nation (2004), on the subject.

${ }^{33}$ Puri, The Caribbean Postcolonial, 49.
} 


\section{III}

\section{The Role of the Arts in Addressing the Multicultural Question}

The contradictory impulses of promoting cultural hybridity as emblematic of the Trinidad nationstate and simultaneously celebrating cultural differences to nurture pride and promote each people's heritage, have been articulated differently at distinct moments in Trinidad's history. In the following text, I focus on the nation-building project in the aftermath of Independence, most particularly in the 1960s and 1970s, and on the articulation of four major forces in the 1990s that have played a major role in redefining how the multicultural question has been addressed. ${ }^{34}$

In the 1960s and 1970s, adopting the liberal rationality of modern nation-states, with their intrinsic paradoxes (celebrating difference and at the same time promoting cultural hybridity as emblematic of the nation-state), the Trinidadian state government set out to recognize difference-both to express its democratic principles and, as Antonio Gramsci would put it, to maintain hegemonic power-by recognizing people's needs or desires and at the same time, keep them under control. ${ }^{35}$ As Kevin Birth indicates, during this period "Popular culture . . became a central concern of governmental planning. ${ }^{36} \mathrm{In}$ 1967, five years after Independence, this recognition of difference was institutionalized and took the form of "The Prime Minister Best Village competitions." These competitions were organized as follows:

The Prime Minister Best Village competitions include all categories of artistic expression (handicraft, steel drum, literature, calypso, dance, "Drummology," and so on) and were organized in each village throughout the country to encourage amateurs from all ethnic groups to develop their artistic talents and promote their cultural heritage. The term "drummology" was created at the height of the Best Village Competitions in the late 1970s and early 1980s in order to include in this category not only drumming, but also chanting and other accompanying performing activities. ${ }^{37}$

These state-sponsored competitions took place in villages across the country, and were initiated after the Prime Minister's 1963 series of tours of various counties. The ensuing new policies were based on the political-economic organization now referred to as "embedded liberalism," 38 established to address community development services and village programs. ${ }^{39}$ However, as Birth reports, "the use of the Better Village Programme to create jobs and improve rural infrastructures came to be overshadowed by the Best Village Competition and similar cultural contests that emphasize talent and artistic performance rather

\footnotetext{
${ }^{34}$ This section of the text draws on various parts of my study, Governing Sound (2007).

${ }^{35}$ The concept of hegemony has been widely deployed by social activists, politicians, and academics, particularly following the work of Antonio Gramsci (1999 [1971]). For an elaboration on the subject, see Williams (1977) and Hall (1986).

${ }^{36}$ Kevin K. Birth, Bacchanalian Sentiments: Musical Experiences and Political Counterpoints in Trinidad (Durham: Duke University Press, 2008), 53-54.

${ }^{37}$ Guilbault (2007: 289n46). For further information on the subject, see also Birth (2008).

${ }^{38}$ My understanding of "embedded liberalism" draws on David Harvey's definition, "to signal how market processes and entrepreneurial and corporate activities were surrounded by a web of social and political constraints and a regulatory environment that sometimes restrained but in other instances led the way in economic and industrial strategy. State-led planning and in some instances state ownership of key sectors (coal, steel, automobiles) were not uncommon" (2005:11). While Harvey here refers to Britain, France, and Italy, his description applies equally well to the form of political-economic organization that Trinidad and Tobago's state government adopted in the 1960s and 1970s.

${ }^{39}$ Susan Craig, 1985. "Political Patronage and Community Resistance: Village Councils in Trinidad." In Rural Development in the Caribbean, ed. P.I. Gomes (1985), 173-93.
} 
than infrastructural improvements." ${ }^{" 40}$ While the competitions helped renew old traditions, including folk dances, parang, Carnival characters and drumming, and succeeded in creating local pride and cohesion, ${ }^{41}$ Birth's illuminating ethnography has shown that: "The Best Village idea has not resulted in widely shared sentiments and ideas about the nation that explicitly include all traditions . . . instead it creates a complicated representation of the politics of participation, competition, and absence." As Birth explains, the choice made by people to participate or not has been telling, demonstrating that the competitions have been more "a vehicle for the promotion of government-fostered images of the nation" than "a context that locally reworks these images." ${ }^{42}$ The display of folk traditions in competitions may have served to keep the communal past of several ethnic groups alive and may have rendered these traditions easily accessible resources for what is often termed in Trinidad the "callaloo" or mixed nation. But the government's promotion of these traditions constituted a project quite separate from and paradoxical to the efforts being deployed to feature a hybrid culture representative of the modern nation-state of Trinidad.

During the same period, the official rhetoric of the state not only openly valued the process of "creolization," but also emphasized the importance of celebrating its product, that is, the hybrid culture that distinguishes Trinidad from other nation-states. However, the celebration of this hybrid culture was highly selective. From the time of emancipation (1834), the colonial elite saw Carnival, the tradition imported to Trinidad by the French plantocracy, and its expressive culture, as a means to inculcate morality and reinforce the colonial order. Carnival thus became a target of power and one of the most important terrains where power could be not only exercised, but also "displayed." Out of the vast repertoire of musical genres and dances of the multinational population of the former slaves and the musical practices they had adopted from the colonial elite, the music that emerged as the most prominent during carnival to the point of becoming a synonym for it, was "calypso." The origins of calypso remain contentious. While associated with the song-dance calinda, several authors view calypso as "ow[ing] its origins to the numerous songs, rhythms, and dance traditions present in Trinidad during the time of African enslavement." ${ }^{43}$ Significantly, it was the characteristics of the calinda-a song-dance that incorporated some of the eccentric and violent movements of stickfighting and thus the embodiment of a dramatic duel, along with lyrics featuring satire and derision-that led the nationalist writers to identify the calinda as the ancestor of calypso. Known for its focus on socio-political commentaries, calypso for Afro-Creole middle-class intellectuals and PNM politicians was the artistic expression that best presented Trinidad's worldview_-even though it embodied a nearly exclusively male Afro-Trinidadian perspective. In all cases, having been the target of power of both the white colonial administration and the middle class for nearly a century and then becoming the privileged music of the PNM - the political party that was to lead the new nation-state for an uninterrupted period of thirty years-calypso acquired a prominence and symbolic importance unequalled by any other music in the country.

In their own ways, recordings of calypso also reinforced calypso's prominence in the country. Following the first commercial recordings by two American companies, Columbia Records and the Victor recording firm, both of whom attempted to give a panorama of the various "ethnic" musics in the island, the local and foreign recordings of Trinidadian music by the late 1920s featured mainly calindas and calypsos. In so doing, these recordings led calypso to acquire not only a commercial value beyond any

\footnotetext{
${ }^{40}$ Birth, 62; Craig, 818.

${ }^{41}$ London (1991); Rohlehr (1997); and Birth (2008), 63.

${ }^{42}$ Birth, 87.

${ }^{43}$ Liverpool (1993), 204; Rohlehr 1990; Cowley 1996.
} 
other music in the island; they also acted as "important symbolic gesture[s] in legitimizing calypso outside Trinidad in the eyes of Trinidadians themselves." ${ }^{44}$ The position of calypso as emblematic of the country became officially recognized when, soon after taking office, the newly elected, predominantly Afro-Creole party in power (the PNM) sought to confirm its independence from the colonial powers not only politically but also culturally. As the first prime minister of the new state government, Eric Williams nationalized Carnival, calypso through its association with Carnival, in Louis Regis's words, "was declared national music." 45 The implications of nationalizing Carnival, and by extension calypso, have been numerous.

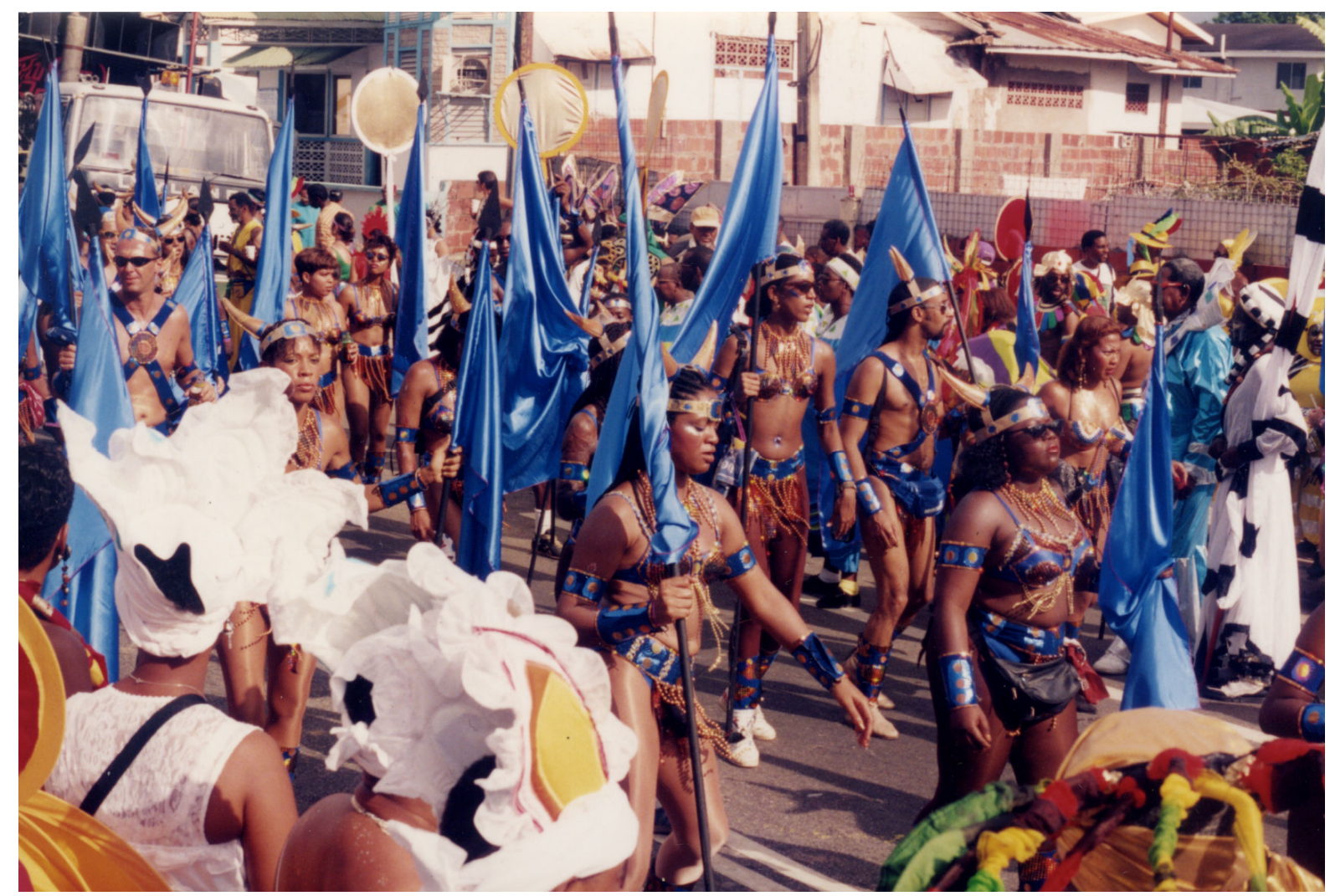

Figure 1. Masquerade revelers on Carnival Tuesday, 1996. Photograph by the author.

\footnotetext{
${ }^{44}$ Donald Hill (1993), 185.

${ }^{45}$ Regis (1999), 16.
} 


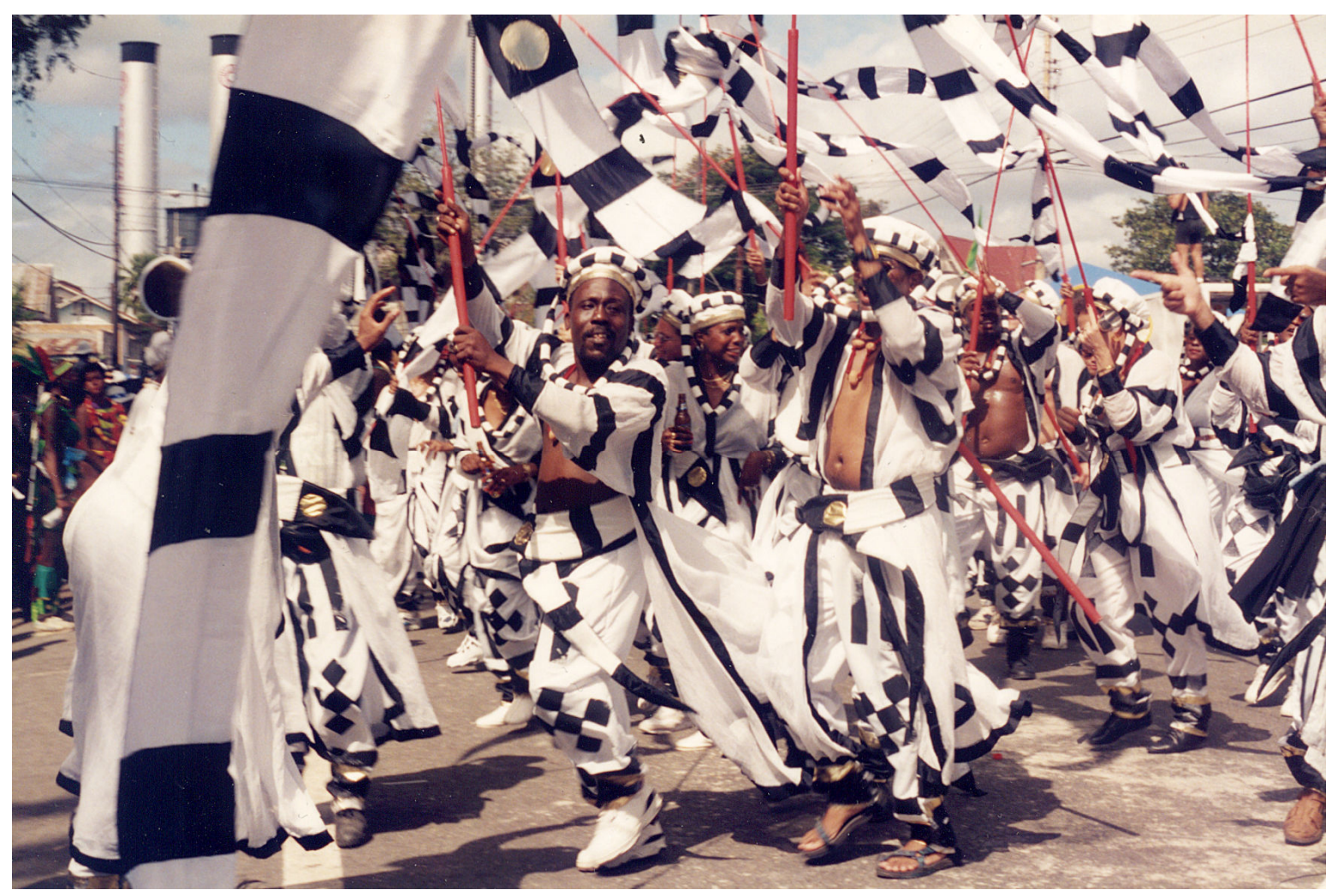

Figure 2. Another Masquerade band on Carnival Tuesday, 1996. Photograph by the author.

Echoing a popular view, Puri remarks, "A central preoccupation of creolization [of hailing a hybrid culture as representative of the nation-state] from the start has been how to establish an Afro-Creole culture as the norm rather than as a deviation from a European market. As such, the discursive complex has concerned itself with cultural status and value, intervening in such areas as education, syllabi, linguistics, the literary canon, and standards of beauty." ${ }^{46}$ Apart from teaching Western musical skills derived from Western classical music, music education in public schools has encouraged students to develop and nurture skills in calypso-a tradition in Trinidad associated nearly exclusively with AfroCreole culture. This has been achieved by organizing calypso competitions, both in individual schools and nationally, to the exclusion of nearly all other musical traditions (including East Indian, Spanish, Lebanese, Chinese) in the island. Along the same lines, national calypso competitions, typically held during Carnival, have received the largest amount of state sponsorship in comparison to all other musical activities in the country. There were also several other initiatives that helped promote calypso as national music. In the aftermath of Independence, several Afro-Trinidadian scholars and journalists, as well as foreign scholars, produced studies and articles, expanding the documentation on calypso already published during the colonial regime-all this to the near exclusion of all other musics performed in the island.

${ }^{46}$ Puri, (2004), 62; Allahar 2000. 
As Peter Manuel puts it, "In general, state cultural policy promoted assimilation to the Creole "mainstream" rather than pluralism. Indians, whom Williams characterized as a 'recalcitrant and hostile minority,' were relegated to the status of political oppositionists and cultural aliens. Although Indian cultural activities were not repressed in any way, Indians realized that, as had always been the case, they would have to sustain their own cultural forms without any support from the state." 47 The major role of Carnival, and thus by extension calypso, during Trinidad's colonial history, combined with the influence of the foreign companies' recordings of calypsos, the preferential disposition of the Afro-Creole PNM towards calypso, and the proliferation of publications on this musical practice by local as well as foreign academics and journalists, have permitted this music a position of privilege in the country. In this context, the construction of an imagined unitary modern Trinidadian subject has thus emerged out of the massive exposure to, and circulation of, a highly selective hybrid musical practice.

The management of diversity in Trinidad took a new turn in the 1990s in connection with four major socio-political and economic forces. These include: the adoption of a neo-liberal rationality in the late 1980s and its attendant deregulation of the local mass media in the early 1990s; the celebration of the $150^{\text {th }}$ anniversary of the Indians' arrival in 1995; in the same year the election for the first time of an East Indian prime minister; and world music trends. The articulation of these contrasting, albeit related forces, greatly transformed the ways in which the question of multiculturalism through the arts has been addressed in the country.

In an article entitled "Imperatives of Caribbean Development for the $21^{\text {st }}$ Century," published in 1989, economist Compton Bourne from the University of the West Indies in Trinidad predicts that the economic crisis in the Caribbean, including Trinidad, would persist and deepen unless development strategies and policies were fundamentally reshaped. Echoing the rationale advanced by the leading industrial countries, he attributes Trinidad's economic crisis to the anti-competitive and antientrepreneurial activities of the state itself. The solution? The state must redirect its mandate and focus on the maintenance of the infrastructure of law and order. The people must ensure their individual and national wellbeing by assuming their responsibilities and developing their own enterprises. As Bourne explains, "The new orthodoxy strongly advocates deregulation, the dismantling of protective and incentive systems, and privatization." ${ }^{48}$ Accordingly, he writes, "the longrun development of the Caribbean nations will ultimately depend upon the sustained effort, creativity, productivity and thrift of individuals and enterprises within the framework of stable supportive and facilatory government policies." 49

Using the premises of neoliberalism, the Trinidadian state-government took a number of initiatives that redefined how it addressed the question of multiculturalism in the arts. Even though it did not completely withdraw its sponsorship for a number of cultural activities on the island, the state presently counts mainly on the private sector to ensure the representation of differences, both nationally and internationally. Less preoccupied by creating a unitary national subject out of diversity, it now views the multicultural, the diversity of hybrid expressions, not only as what should define the country, but also as a field of commercial potential. This shift in logic means that the question is less about what the state can do for its citizens, but rather what the citizens can do for the country; it is less about constructing a selective

\footnotetext{
${ }^{47}$ Manuel, (2000, a), 58.

${ }^{48}$ Bourne (1989), 276.

${ }^{49}$ Ibid., 278. My emphasis.
} 
and single cultural hybridity to represent the country and more about asking the many hybrid cultures that make up Trinidad to help fortify it.

The Trinidad state-government's deregulation of the media also brought a dramatic change of soundscape. As Robin Balliger (2000: 55) wrote, "Privatization has included media expansion, niche marketing, and Trinidad is [now] one of the most media-saturated environments in the Caribbean." ${ }^{20}$ After over thirty years of operating a state-owned television broadcasting monopoly (from 1962-1991), the state government began to grant licenses to individuals and private enterprises. A 2007 report indicates that Trinidad boasted as many as seven television stations and four local cable-only television stations. ${ }^{51}$ Along the same lines, the state government relinquished its control of radio stations and privatized this sector. In 2010 there are thirty-three radio stations within Trinidad. ${ }^{52}$ While some stations feature musics and cultural programs that are nearly exclusively either Afro or Indo-Trinidadian, others offer a broad range of artistic expression that is inclusive of the two main ethnic groups. The privatization of the media services enabled several local musical expressions formerly overshadowed by calypso to be more easily heard and, in some cases (e.g., soca and chutney soca associated respectively with Afro- and Indo-Trinidadians) to acquire a greater economic value. ${ }^{53}$

Together with the privatization of broadcasting media, the rise of private entrepreneurship in the arts encouraged by the state has also greatly contributed to the promotion of several hybrid musics nationally. After more than half a century of monopoly, the state-sponsored calypso competition saw the emergence of new privately sponsored carnival competitions for the musical styles of soca (in 1993), chutney soca (in 1996), and ragga soca (in 1999). ${ }^{54}$ Held during the Carnival period, only a few days apart from the calypso competition, and adopting its format (semi-finals and finals, and placing a jury in charge of establishing competition criteria and choosing winners), these competitions helped calypso's musical offshoots gain both recognition and a legitimacy of their own. More importantly, in addition to generating revenues locally, what these national competitions have achieved-most likely as an inadvertent outcome of the state's adoption of neoliberal policies-is the promotion and capitalization on more than one cultural hybridity as constitutive and representative of the nation-state and of its national subjects.

The explosion of radio and television stations and the rise of cultural entrepreneurship in several artistic ventures (particularly in relation to national competitions during Carnival in Trinidad) did not stem simply from economic pursuits, but also from political interests. Several individuals, IndoTrinidadians in particular, seized this neoliberal moment as an opportunity both to make their voices heard and to enjoy their fair share of the market through greater exposure. After being told not to bring the Chutney Soca Monarch competition into Carnival because this meant "putting Indian business in African business," where the two would not mix, George Jr. Singh, the founder of the chutney soca competition, became all the more determined to succeed. Not surprisingly, Singh thus views the success of the chutney

\footnotetext{
${ }^{50}$ Robin Balliger (2000: 55).

51 "Introduction Media Lifestyle Statistics" by UNSW Wikispaces.

http://arts1091.unsw.wikispaces.net/Trinidad+and+Tobago, accessed on September 9, 2010. Please note, however, that

Trinbago media sources lists ten television stations, http://www.tntisland.com/media.html, accessed on September $12,2010$.

${ }^{52}$ Trinbago media sources. http://www.tntisland.com/media.html, accessed on September 12, 2010.

${ }^{53}$ For an in-depth discussion of the rise of Indian-owned radio and television stations, see Diethrich (2004).

${ }^{54}$ Soca emerged in the late 1960s, early 1970s, out of a fusion of some East Indian rhythmic patterns and musical instruments combined with calypso rhythm section. Chutney soca refers to a fusion between chutney-an East Indian musical practice associated by some to mathkor, which Tina K. Ramnarine defines as "religious celebration which is part of Sanatanist Hindu weddings" (2001: 152)—and soca. Ragga soca refers to a fusion between dancehall from Jamaica and soca. For further information on the subject, see Manuel (2000a), Ramnarine (2001), and Guilbault (2007).
} 
soca competition not only in economic terms, but also in relation to the cultural work it has accomplished. Here is how he put it when I interviewed him, "[Today] no longer African people think twice to dance and enjoy chutney soca. It has become totally part of Trinidad.”

In addition to the deregulation of the broadcasting media and the proliferation of national competitions, two other forces enabled the multicultural heterogeneity in Trinidad to be better represented and valued, both politically and economically: the celebration in 1995 of the $150^{\text {th }}$ anniversary of Indian arrival and, in the same year, the election of an East Indian Prime Minister for the first time since Independence. As Gregory Michael Diethrich (2004) indicated, until then, few publications on East Indian music from Trinidad existed. The historical and political events of 1995 not only bolstered ethnic pride, but also prompted East Indian as well as non-East Indian scholars to document East Indian musical practices and their contributions to the country. Compared to the few publications on East Indian musics and the irregular pace at which they appeared in the past, between 1991 and 2000 alone, the following publications appeared: Baksh-Soodeen (1999), Balkaransingh, (1999), Constance (1991), Karran (1997), Manuel (1997/1998, 1998, 2000a, 2000b, 2000c), Meyers (1991, 1993, 1998), Patasar (1995, 1996, 1998), Puri (1999), and Ramnarine (1996), and Ravi-ji (1998). The events of the $150^{\text {th }}$ anniversary of Indian arrival, along with the election of the first East Indian Prime Minister, also undoubtedly encouraged several students to focus on East Indian musical traditions, as illustrated by the numerous papers written on the subject during that period through the Caribbean Studies Project at the University of the West Indies, Trinidad. ${ }^{55}$ Even though far less influential than the new broadcasting media and national competitions, these publications and research papers-particularly those on chutney and chutney socanonetheless also contributed to the creation of a new habitus in the country. For most Trinidadians today, it has indeed become "normal" to recognize not only one, but several musical hybrids as representative of the modern nation-state of Trinidad, and to acknowledge their economic value.

The political and economic valuation of cultural hybridities in Trinidad can also be traced to the world music trends that have influenced local musicians and publics alike. With the advent of new mass communication channels, such as cable TV and the internet, along with the ease of travel today, most Trinidadians are exposed daily to world music trends and are deeply influenced by them. The focus on mixing styles and artists from different times and places in many musics such as hip hop and banghra, to name only a few, has encouraged many Trinidadian artists, particularly those involved in soca, chutney soca, and ragga soca, to develop and reinforce alliances through collaborations on stage and in recordings. These have ranged from working with artists from other ethnic groups (Indo- or Afro-Trinidadian, depending on the case) in Trinidad, with artists from other islands (including Jamaica, Barbados, and Antigua), with West Indians living in diaspora (e.g., with Wyclef Jean from Haiti, who lives in New York), and in a few cases with African American artists. It is significant, however, while many Trinidadian artists have developed musical tastes and collaborations that have embraced local multicultural heterogeneity (Afro- and Indo-Trinidadian musical sensibilities and experiences), their collaborations with artists and promoters outside of Trinidad have typically helped to strengthen ethnic ties. Afro-Trinidadian artists collaborate usually with artists and promoters from the African diasporas, while Indo-Trinidadian artists similarly work mainly with artists and promoters from the Indo-diasporas-in the two cases, diasporas that are mainly in the Caribbean, North America, and England. More often than not, to paraphrase Peter

\footnotetext{
${ }^{55}$ See, for example, Mohammed (2000), Persad (2000), Ramaya (1990), Ribeiro (1992), Smith (1998), and Syriac (1993).
} 
Manuel (2000a: 204), the social geography that is produced through these circuits is thus transnational Indian or transnational African. ${ }^{56}$

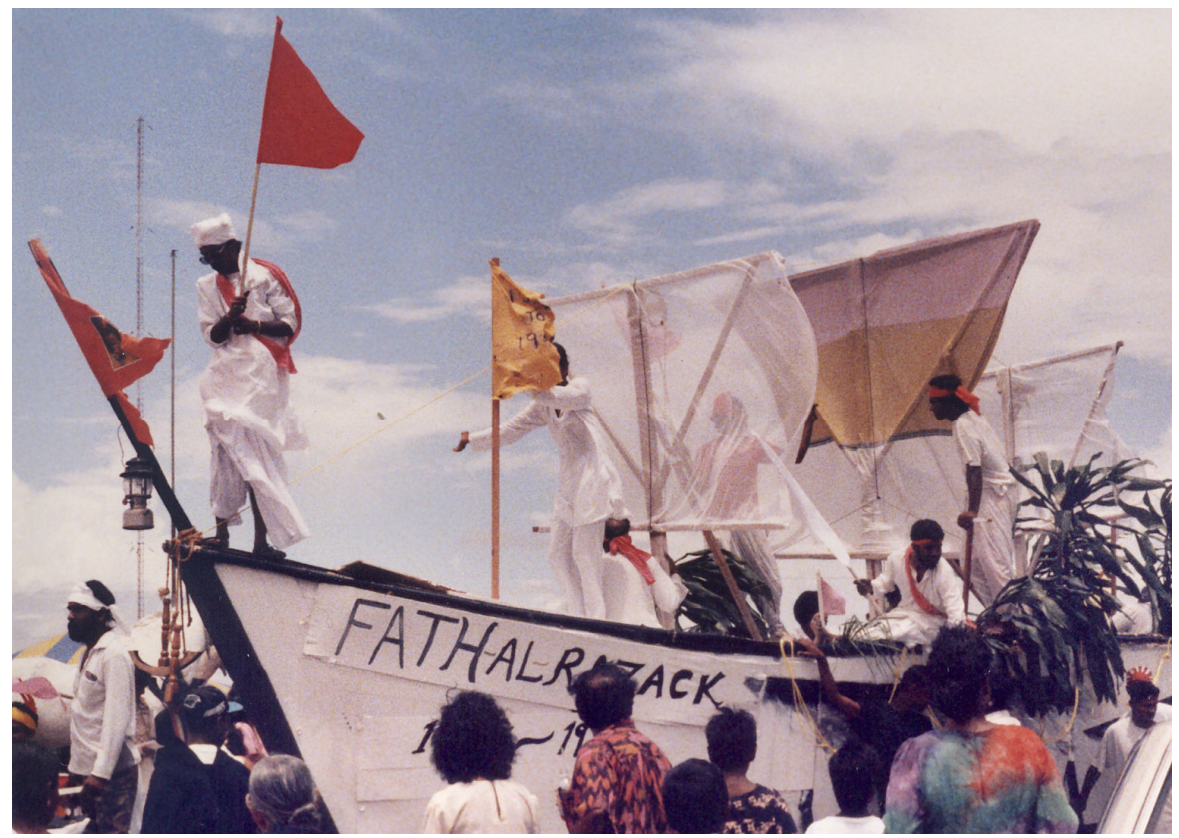

Figure 3. At the celebration of the $150^{\text {th }}$ Anniversary of Indian Arrival in 1995, a float represented the boat Fath-alrazak (also known as "Fatel Rozack") that brought the first group of Indians to Trinidad. Photograph by the author.

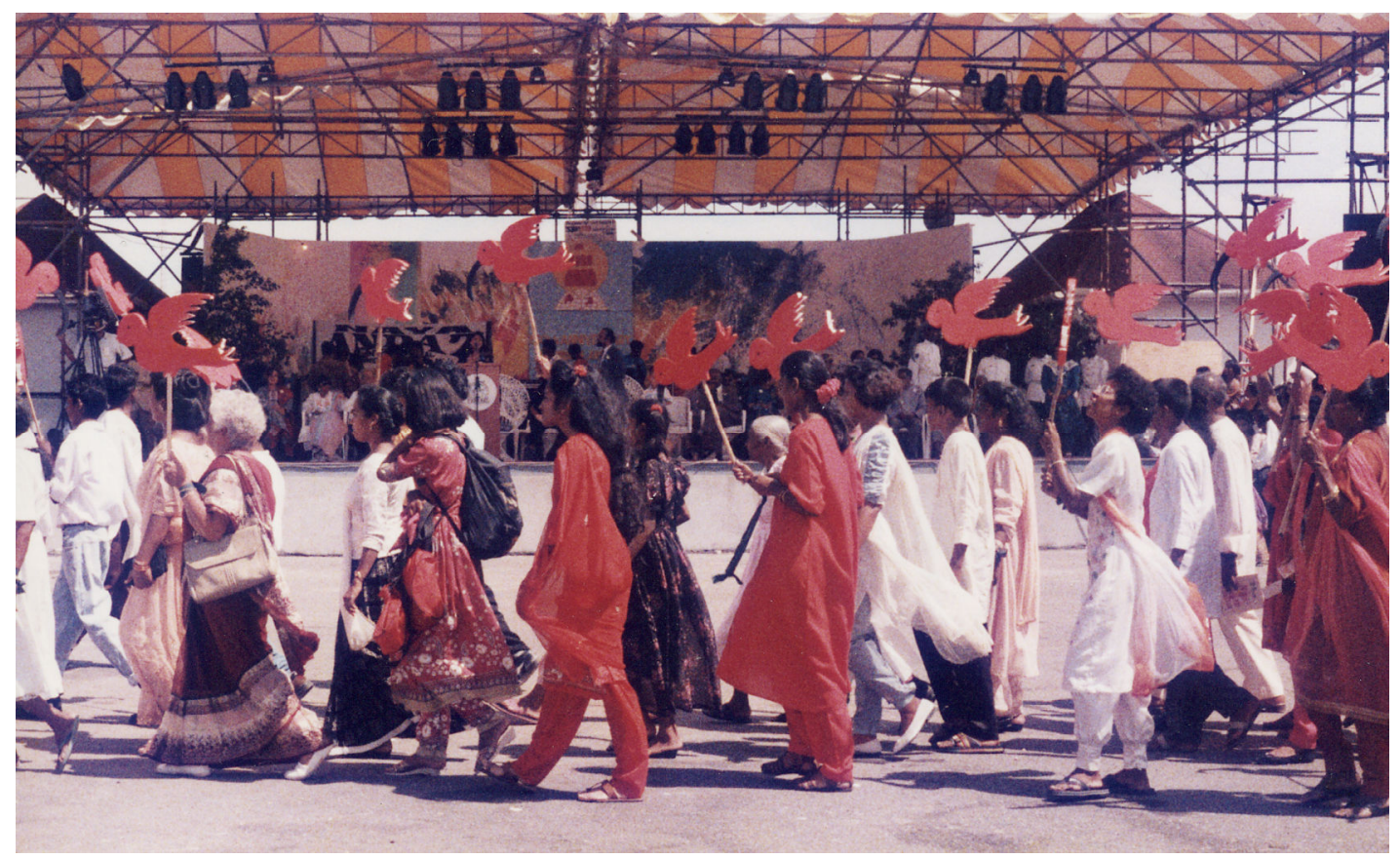

Figure 4. At the celebration of the $150^{\text {th }}$ Anniversary of Indian Arrival, a group of women and men in traditional Indian attire. Photograph by the author.

\footnotetext{
${ }^{56}$ Manuel (2000, a), 204.
} 
If the articulation of the many forces examined so far - the deregulation of the media, the rise of cultural entrepreneurs, and the work of journalists and researchers-has helped the cultural hybridities to gain political recognition and to accrue economic value, the racialization of popular consciousness in Trinidad persists. As Anton Allahar (2000: 248) explains, "The racialization of consciousness speaks to the tendency for racial differences to be perceived as crucial in determining political actions, economic opportunities, social standing, even cultural legitimacy or authenticity." 57 Hence when Gypsy, a Trinidadian calypsonian of African descent, performed at the semi-finale of the calypso monarch competition in 2002 - an event attended by a majority of Afro-Trinidadians-he was pelted with toilet paper for having teamed up with the United National Congress (UNC), formed primarily of Trinidadians of Indian descent. ${ }^{58}$ Even for Rikki Jai, one of the most recognized East Indian artists who has won competitions in several styles (calypso, soca, chutney, and chutney soca) associated with both Afro- and Indo-Trinidadian practices, his audiences and his performance venues continue to remain primarily East Indian. In other words, race continues to limit the artists' access to particular networks and spaces. And in turn, their musical practices continue to be racialized, in spite of the many efforts to resist the association of particular musics with fixed and stable identities.

\section{Concluding remarks}

One of the main paradoxes posed by the question of multiculturalism, to return to Lisa Lowe's remarks, is that while it aims to promote multicultural inclusion, it divides communities and people in separate categories. As we have seen in the case of Trinidad, even when the official rhetoric of the state after Independence was to avoid the division of people into categories and to promote cultural hybridity as the distinguishing feature of the new modern-state, the cultural hybridity that emerged as synonymous with the nation-state was highly selective. Ultimately, it was linked to whoever had the authority to create norms and social hierarchies. What I have tried to highlight is that the governance of multicultural communities, and the creation of norms and social hierarchies through the arts, is intimately linked to what Line Grenier and I have referred to as the "regimes of circulation." These regimes, which participate in the regulation of what and who circulates, as well as where and why, are not only local or state-wide, but also involve "the conjunctural linkages of other institutions and discourses." 59 In other words, the prominence of the selective cultural hybridity of calypso as emblematic of the country and its unparalleled influence in the arts locally, must be linked not only to the colonial legacy of carnival and the privileging of calypso by the Afro-Creole political party in power, but also to American and local recording companies, and the Trinidadian and non-Trinidadian journalists and academics who have helped expand its recognition and commercial value both locally and internationally.

What I have tried to highlight also is that the regimes of circulation that inform the management of diversity and multiplicity are conjuncturally and historically contingent. The articulation of four key forces in Trinidad in the 1990s, which I referred to earlier, destabilized the prominence of calypso as the sole cultural hybridity representative of the country. The adoption of the neoliberal rationality by the state government and the ensuing deregulation of the media, combined with both the surge of ethnic pride that accompanied the $150^{\text {th }}$ anniversary of Indian arrival and the election of the first East Indian prime minister,

\footnotetext{
${ }^{57}$ Allahar (2000), 248.

${ }^{58}$ Singh (2002).

${ }^{59}$ Grenier and Guilbault (1997), 230.
} 
encouraged the documentation of East Indian musical practices and of their contributions to the country. In addition, the influence of world music trends on local practices has had tangible effects on how the question of multiculturalism is now addressed in Trinidad. In combination, these contrasting and yet related forces have greatly helped nurture not only new sensibilities, but also senses of belonging (in the plural) that go well beyond the confines of the territory of Trinidad. At the same time, they have helped make several cultural hybridities more audible and visible as constitutive and representative of the nationstate. From this perspective, I thus agree with Peter Manuel when he writes, "In this sense, chutney [soca] has not only symbolized the emergence of a new social paradigm of multiculturalism, but has also played a formative role in the process." 60

One other point that I have not developed in the paper but which, following several authors, I would like to make now, is that the display of various "ethnic" musics (as was the case with the Best Village Competitions) or even the selection of a music as emblematic of a country (as has been the case with calypso) "is not an analogue for the material positions, means, or resources of these populations." ${ }^{\text {"1 }}$ While it may have provided additional income and opportunities to musicians, artists and other people connected to the calypso music industry, the representation of Afro-Trinidadians through calypso has not translated in better economic positioning or opportunities for them. As Ralph R. Premdas writes, "Since Independence, political stability in Trinidad was maintained by a system of "balance" whereby African Creoles controlled the polity and Indians and others, including the descendants of whites, dominated the area of agriculture, commerce and business." ${ }^{62}$ While there are very poor people in both the Afro and Indo-Trinidadian communities, the "Indian-European community," in Premdas's own words, has dominated the economy. ${ }^{63}$ Hence the ways in which the question of multiculturalism is articulated through the arts should be de-linked from the question of equality of access to economic resources and opportunities. The hierarchies that inform one domain are not necessarily the same as those prevailing in other domains; moreover, the rapport within these hierarchies is in and of itself conjunctural.

The last point is that even though the question of multiculturalism has been conceived in Trinidad, as in many other countries, as going beyond race, it has indeed provided a new terrain on which to deploy as well as to resist it. Whether it is in the selection of the cultural hybridity (calypso) to represent the nation-state during the nationalist movement and through the nation-building project, or on the international circuits in which the new hybrid Indo- or Afro-Trinidadian musics mainly travel, race continues to function as an organizing principle in the management of diversity.

\footnotetext{
${ }^{60}$ Manuel (2000, a), 195.

${ }^{61}$ Lowe (1996), 414.

${ }^{62}$ Premdas (2000), 324.

${ }^{63}$ Ibid., 325.
} 


\section{References}

Allahar, Anton. "Popular Culture and Racialisation of Political Consciousness in Trinidad." In Identity, ethnicity and Culture in the Caribbean, edited by Ralph R. Premdas, 246-81. St. Augustine, Trinidad: School of Continuing Studies, the University of the West Indies, 2000.

Baksh-Soodeen. "Stereotypes of Negroes and East Indians in Trinidad: a Reexamination." Caribbean Quarterly 25, no. 1-2 (1999): 52-71.

Balkaransingh, Satmarine. "Chutney Crosses Over into Chutney Soca in Trindiad and Tobago Carnival." in Identity, ethnicity and Culture in the Caribbean, edited by Ralph R. Premdas, 47-53. St. Augustine, Trinidad: School of Continuing Studies, the University of the West Indies, 1999.

Balliger, Robin. "Popular Music and the Cultural Politics of Globalisation among the Post-Oil Boom Generation in Trinidad." In Identity, Ethnicity and Culture in the Caribbean, edited by Ralph R. Premdas, 54-79. St. Augustine, Trinidad: School of Continuing Studies, the University of the West Indies, 2000.

Birth, Kevin K. Bacchanalian Sentiments: Musical Experiences and Political Counterpoints in Trinidad. Durham: Duke University Press, 2008.

Bourne, Compton. "Imperatives of Caribbean Development for the $21^{\text {st }}$ Century." In CALACS/ACELAC Conference Proceedings: Prospects for Latin America and the Caribbean to the Year 2000, ed. A. R. M. Ritter. 266-78. Ottawa: CALACS/ACELAC, 1989.

Brereton, Bridget. Race Relations in Colonial Trinidad 1879-1900. Cambridge: Cambridge University Press, 2002 [1979].

Constance, Zeno Obi. Tassa, Chutney and Soca: The East Indian Contribution to the Calypso. Trinidad: published by the author, 1991.

Cowley, John. Carnival, Canboulay and Calypso: Traditions in the Making. Cambridge: Cambridge University Press, 1996.

Craig, Susan. "Political Patronage and Community Resistance: Village Councils in Trinidad." In Rural Development in the Caribbean, edited by P.I. Gomes, 173-93, 1985.

Diethrich, Gregory Michael. "Living in Both Sides of the World': Music, Diaspora, and Nation in Trinidad.” Ph.D. diss., University of Illinois, Urbana-Champaign, 2004.

Downes, Gillian. "Caribana." The Toronto Times, 3 August 2008. http://thetorontotimes.com/ content/view/234/63, accessed on 11 August 2008.

Foucault, Michel. “On Governmentality.” Ideology and Consciousness, 5: 5-22.

Goldberg, David Theo. 1994. "Introduction: Multicultural Conditions." In Multiculturalism, a Critical Reader, edited by David T. Goldberg, 1-44. Oxford: Basil Blackwell, 1979.

Gordon, Avery F. and Christopher Newfield (eds). "Introduction." Mapping Multi-Culturalism, 1-16. Minneapolis: University Press of Minnesota Press, 1996. 
Gramsci, Antonio. Selections from the Prison Notebooks, edited and translated by Quintin Hoare and Geoffrey Nowell Smith. New York: International Publishers, 1999 [1971].

Grenier, Line and Jocelyne Guilbault. "Créolité and Francophonie in Music: Socio-Musical Repositioning Where It Matters.” Cultural Studies 11, no. 2 (1997): 207-34.

Guilbault, Jocelyne. Governing Sound: The Cultural Politics of Trinidad's Carnival Musics. Chicago: University of Chicago Press, 2007.

Hall, Stuart. "Gramsci's Relevance for the Study of Race and Ethnicity." Journal of Communication Inquiry 10, no. 2 (1986): 5-27.

Hall, Stuart. "Conclusion: the Multi-Cultural Question. In Un/Settled Multiculturalisms: Diasporas, Entanglements, Transruptions, edited by Barnor Hesse, 209-41. New York: St. Martin’s Press, 2000.

Harvey, David. A Brief History of Neoliberalism. Oxford: Oxford University Press, 2005.

Hesse, Barnor. "Introduction: Un/Settled Multiculturalism.” In Un/Settled Multiculturalisms: Diasporas, Entanglements, Transruptions, edited by Barnor Hesse, 1-30. New York: St. Martin’s Press, 2000.

Hintzen, Percy C. The Costs of Regime Survival: Racial Mobilization, Elite, Domination and Control of the State in Guyana and Trinidad. Cambridge: Cambridge University Press, 1989.

—. "The Caribbean: Race and Creole Ethnicity." In The Blackwell Companion to Racial and Ethnic Studies, edited by David Theo Goldberg and John Solomos, 475-94. Oxford: Blackwell, 1999.

Karran, Kampta. "Ethnic Music in Trinidad: Parang, Calypso and Chutney." In Race Relations in Trinbago: Afro- and Indo-Trinbagonians and Basdeo Panday, edited by F. B. Ramadar, 37-56. New York: East Indian Diaspora Committee, 1997.

Khan, Aisha. Callaloo Nation: Metaphors of Race and Religious Identity among South Asians in Trinidad. Durham: Duke University Press, 2004.

Koningsbruggen, Peter van. Trinidad Carnival: A Quest for National Identity. London: Macmillan, 1997.

Liverpool, Hollis. "Rituals of Power and Rebellion: The Carnival Tradition in Trinidad." Ph.D. diss., University of Michigan, 1993.

London, Clement B.G. 1991. "Forging a Cultural Identity: Leadership and Development in Mass Education in a developing Caribbean Country.” Journal of Black Studies 21, no. 3 (1991): 251-67.

Lowe, Lisa. "Imagining Los Angeles in the Production of Multiculturalism." In Mapping Multi-Culturalism, edited by Avery F. Gordon and Christopher Newfield, 413-23. Minneapolis: University Press of Minnesota Press, 1991.

Manuel, Peter. "Music, Identity, and Images of Indian in the Indo-Caribbean Diaspora." Asian Music 29, no. 1 (1997/1998): 17-35.

. "Chutney and Indo-Trinidadian Cultural Identity.” Popular Music 17, no. 1 (1998): 21-43. 
. East Indian Music in the West Indies: Tan-Singing, Chutney, and the Making of Indo-Caribbean Culture. Philadelphia: Temple University, 2000. (a).

- "The Construction of a Diasporic Tradition: Indo-Caribbean 'Local Classical Music." Ethnomusicology 44, no. 1 (2000): 97119. (b).

—. "Ethnic Identity, National Identity, and Music in Indo-Trinidadian Culture." In Music and the Racial Imagination, edited by Ronald Radano and Philip V. Bohlman, 318-45. Chicago: University of Chicago Press, 2000. (c).

Mohammed, Cindy Ann. "Radio Stations and the Promotion of East Indian Culture in Trinidad." Caribbean Studies Project, University of the West Indies, Trinidad, 2000.

Mohanty, Satya. "Epilogue. Colonial Legacies, Multicultural Futures: Relativism, Objectivity, and the Challenge of Otherness." PMLA 110, no. 1 (1995): 108-18. Special topic: Colonialism and the Postcolonial Condition.

Myers, Helen. "Indian, East Indian, and West Indian Music in Felicity, Trinidad." In Ethnomusicology and Modern Music History, edited by Stephen Blum et al., 231-41. Urbana: University of Illinois Press, 1991.

_. "Indian, East Indian and West Indian Music in Felicity, Trinidad." In Ethnomusicology and Modern Music History, edited by Stephen Blum, Philip V. Bohlman, and Daniel M. Neuman, 231-41. Chicago: The University of Illinois Press, 1993.

- Music of Hindu Trinidad: Songs from the India Diaspora. Chicago: The University of Chicago Press, 1998.

Patasar, Mungal. "Modern Trends in Indo-Trinidad Music." In Celebration of 150 Years of the Indian Contribution to Trinidad, vol. 2, edited by Brinsley Samaroo et al, 75-85. Port of Spain: Historical Publications, 1995.

— Great Britain, Filmakers Library, 1996.

—. "The Development of Indian Music in Trinidad." Caribbean Dialogue 3, no. 4 (1998): 67-71.

Persad, Michael Colin. "The Evolution of Bhajan Singing in the Presbyterian Church in Trinidad and Tobago.” Caribbean Studies project, University of the West Indies, Trinidad, 2000.

Premdas, Ralph R. "The Ascendance of an Indian Prime Minister in Trinidad and Tobago: the 1995 Elections." In Identity, Ethnicity and Culture in the Caribbean, edited by Ralph R. Premdas, 323-58. St. Augustine, Trinidad: School of Continuing Studies, the University of the West Indies, 2000.

Puri, Shalini. "Canonized Hybridities, Resistant Hybridities: Chutney Soca, Carnival, and the Politics of Nationalism." In Caribbean Romances: The Politics of Regional Representation, edited by B.J. Edmondson, 12-38. Charlottesville: University Press of Virginia, 1999.

. The Caribbean Postcolonial: Social Equality, Post-Nationalism, and Cultural Hybridity. New York: Palgrave Macmillan, 2004. 
Praimsingh, Ajeet. "Trinidad Chutney Music: Letter to the Ministry of Culture." http://www.ajeetpraimsingh.com/ministry_of_culture.htm, accessed on 3 July 2008.

Ramaya, Narsaloo. "Chutney Singing: Its Origin and Development in Trinidad and Tobago.” Manuscript, West Indies Collection, University of the West Indies Library, 1990.

Ramnarine, Tina Karina. 1996. “'Indian' Music in the Diaspora: case Studies of 'Chutney' in Trinidad and London.” British Journal of Ethnomusicology 5 (1996): 133-53.

- 2001. Creating Their Own Space: The Development of an Indian-Caribbean Musical Tradition. Mona, Jamaica: University of the West Indies Press, 2001.

Ravi-ji. "The Development of Indian Music in Trinidad and Tobago." Caribbean Dialogue: A Journal of Contemporary Caribbean Policy Issues 3, no. 4 (1998): 73-76.

Ribeiro, Indra. "The Phenomenon of Chutney Singing in Trinidad and Tobago: The Functional Value of a Social Phenomenon.” B. A. thesis, University of the West Indies, St. Augustine, 1992.

Rifkin, Jeremy. The Age of Access: The New Culture of Hypercapitalism, Where All of Life Is a Paid-for Experience. New York: Jemery P. Tarcher/Putnam.

Regis, Louis. 1999. The Political Calypso: True Opposition in Trinidad 1962-1987. Trinidad: The Press University of the West Indies, 2000.

Rohlehr, Gordon. Calypso and Society in Pre-Independence Trinidad. Port of Spain, Trinidad: published by the author, 1990.

—. "The Culture of Williams: Context, Performance, Legacy. Callaloo 20, no. 4 (1997): 849-88.

Singh, Rickey. “Toilet Paper Caper on 'Gypsy.” Guyana Chronicle, 12 February 2002.

Scott, Joan W. "Multiculturalism and the Politics of Identity.” October 61 The Identity in Question (1992): 12-19.

Smith, Tricia L. "Chutney Soca: The Fusion of Two Cultural Art Forms." Caribbean Studies project, University of the West Indies, Trinidad, 1998.

Syriac, Sharon. "The Phenomenon of Chutney." Caribbean Studies project, University of the West Indies, Trinidad, 1993.

Williams, Eric. History of the People of Trinidad. Port of Spain, Trinidad: PNM Publishing Co., 1962 [1961].

Williams, Raymond. Marxism and Literature. Oxford: Oxford University Press, 1977.

Young, Iris Marion. Inclusion and Democracy. New York: Oxford University Press, 2000.

Yúdice, George. The Expediency of Culture: Uses of Culture in the Global era. Durham: Duke University, 2003. 